\title{
En kvinne med kronisk hoste og dyspné
}

\author{
En tidligere frisk kvinne i 40-årene oppsøkte allmennlege grunnet lang- \\ varig hoste, tung pust og tretthet. Dette er generelle symptomer som \\ kan representere en rekke sykdommer.
}

Se kommentar side 1469

\author{
Ziaullah Kamal \\ zika@ulleval.no \\ Geir Øystein Andersen \\ Gunnar Smith \\ Kardiologisk avdeling \\ Frøydis Stornes \\ Lungemedisinsk avdeling \\ Knut Haakon Stensæth \\ Avdeling for Radiologi og nukleærmedisin \\ Jan Eritsland \\ Kardiologisk avdeling \\ Oslo universitetssykehus, Ullevål
}

Pasienten hadde vært plaget med hoste, ekspektorat, dyspné, nattesvette, subfebrilia og generell tretthet i fire uker da hun kontaktet allmennlege. Blodprøver viste forhøyet nivå av C-reaktivt protein (CRP) på $39 \mathrm{mg} / \mathrm{l}(0-10 \mathrm{mg} / \mathrm{l})$, leukocytose med hvite blodceller på $12 \cdot 10^{9} / \mathrm{l}\left(3,5-10 \cdot 10^{9} / \mathrm{l}\right)$ og nøytrofili på $10 \cdot 10^{9} / \mathrm{l}\left(2,0-7,5 \cdot 10^{9} / \mathrm{l}\right)$. Bortsett fra moderate ryggplager hadde pasienten tidligere stort sett vært frisk. Hun var slank og trente minst tre ganger i uken inntil det aktuelle. Fra hun var 18 år til hun kom i 30-årene røykte hun daglig, etter det bare av og til. Det var familiær belastning for lymfom.

Allmennlegen oppfattet tilstanden som luftveisinfeksjon, og hun fikk initialt en antibiotikakur med doksysyklin på mistanke om atypisk pneumoni. Det ble skiftet til penicillin etter tre dager, da det ikke var effekt. Kvinnen kunne ikke jobbe eller trene som normalt og ble sykmeldt noen kortere perioder. Symptomene ble etter hvert mindre uttalte, men hun hadde fortsatt vedvarende moderate symptomer med tørrhoste, dyspné og generell tretthet. Allmenntilstanden var imidlertid bra, slik at hun ikke kontaktet allmennlegen igjen før det var gått flere måneder.

Kronisk hoste, dyspné og tretthet er generelle symptomer og kan representere en rekke sykdommer. Den vanligste årsaken til slike symptomer er luftveisinfeksjoner, men astma/allergi, hjertesvikt, ikke-infeksiøse kroniske interstitielle lungesykdommer, lungetumorer og en del sjeldne lungesykdommer kan også manifestere seg på samme måte. Diagnosen var fortsatt uavklart.

Muligheten for at det kunne foreligge atypisk pneumoni, tuberkulose eller lungetumor gjorde at allmennlegen henviste pasienten til videre utredning med bildediagnostikk, i første omgang røntgen thorax.

Røntgen thorax tatt omtrent et halvt år etter symptomdebut viste en litt uskarpt avgrenset fortetning i tilknytning til høyre lungehilus. Supplerende computertomografi (CT) av thorax viste en relativt velavgrenset solid fortetning, $3,7 \times 3,4 \times 3,5 \mathrm{~cm}$, $i$ nedre del av høyre lungehilus (fig 1). Blodprøvene viste nå normal CRP, hvite blodceller og senkningsreaksjon (SR). Pasienten hadde tørrhoste, anstrengelsesrelatert dyspné og vedvarende moderate plager $i$ den grad at hennes fysiske yteevne var redusert. Hun hadde ingen kjent astma eller allergi. På grunn av vedvarende symptomer og røntgenfunn ble hun henvist til snarlig utredning ved lungepoliklinikken.

En lungefortetning kan være et alvorlig funn og krever snarlig avklaring, særlig med tanke på malignitet. Fortetninger i lungehilus kan representere både maligne og benigne tilstander. Av maligne tilstander må man blant annet tenke på primær lungetumor, lymfom og metastaser. Fortetninger kan også ha infeksiøs årsak, for eksempel pneumonisk infiltrat eller abscess. Andre differensialdiagnoser kan være atelektase, granulomer eller benigne tumorer. For nærmere diagnostikk bør det gjøres bronkoskopi med cytologisk og bakteriologisk prøvetaking. Samtidig bør det tas CT- eller ultralydveiledet biopsi, enten transbronkialt eller perkutant.

Det ble utført spirometri, som viste normale verdier. Bronkoskopi viste lett injiserte slimhinner i høyre overlapp. Cytologisk undersøkelse av bronkial skylleprøve viste normalt respiratorisk epitel og makrofager. Det var ingen vekst av mikrober, inklusive mykobakterier, ved dyrking av bronkial skylleprøve. Det ble foretatt CT-veiledet punksjonsbiopsi av tumor. Undersøkelse av biopsimaterialet viste lymfoproliferativ tilstand av usikker årsak.

Lymfoproliferativ forandring defineres som en tilstand der lymfocytter produseres i store mengder. Dette er et uspesifikt funn. Tilstanden ses ved flere sykdommer, blant annet lymfomer, immunologiske sykdommer og kroniske infeksjoner. For nærmere avklaring kan det gjøres immunohistokjemiske undersøkelser av biopsimaterialet med tanke på lymfomdiagnostikk. Man kan vurdere spesifikke bildeundersøkelser som magnetisk resonanstomografi (MR) og positronemisjonstomografi (PET) med tanke på nærmere kartlegging av tumor. Det bør også tas supplerende blodprøver med tanke på systemsykdom.

Biopsipreparatene ble revurdert med blant annet immunhistokjemiske undersøkelser. Det var ingen tegn til Hodgkins lymfom, og man kunne ikke finne typiske granulomer. Morfologien passet heller ikke med tuberkulose, og det ble ikke påvist syrefaste staver ved spesialfarging. Konklusjonen var at det var nødvendig med større biopsimateriale for sikker diagnose. Blodprøver med tanke på infeksjon, tumormarkører og systemsykdom var upåfallende, bortsett fra lett forhøyet nivå av angiotensinkonvertase (ACE) på 114 U/l (20-100 U/l). Senere kontroller av ACE viste normale verdier. Pasienten hadde normalt serum-kalsiumnivå. MR thorax og CT thorax tatt målrettet for tumordiagnostikk bekreftet fortetningen i høyre lungehilus, men ga ikke ytterligere diagnostisk avklaring. PET-undersøkelse av thorax konkluderte med mulig malignitetssuspekt lesjon i nedre del av høyre lungehilus. Pasienten ble også vurdert med tanke på

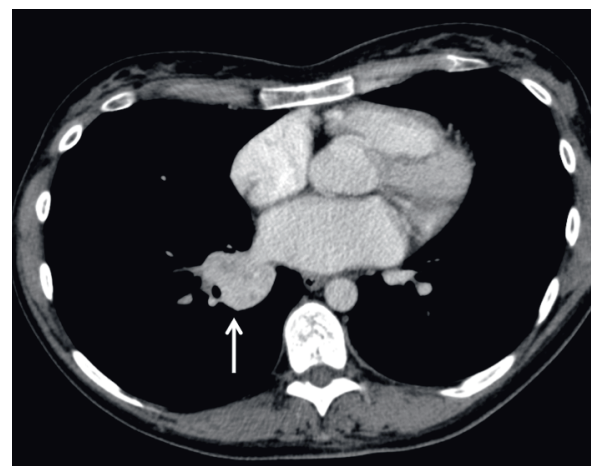

Figur 1 CT thorax viser perihilær fortetning i høyre lunge (pil) 
endobronkial ultralydveiledet nålebiopsi, men tumoren ble ikke ansett å være tilgjengelig for slik prosedyre.

Pasienten var plaget av palpitasjoner, moderat redusert fysisk yteevne og redusert pulsstigning ved anstrengelse. Det var ingen synkope eller nærsynkope $i$ anamnesen. Under oppfølgingen, omtrent sju måneder etter symptomdebut, fant man ved klinisk undersøkelse en systolisk bilyd, som hørtes best over apeks, samt tegn til venstre ventrikkel-hypertrofi og sinusbradykardi på EKG. Bilyden var ikke bemerket ved tidligere kliniske undersøkelser. Blodtrykket var normalt ved alle konsultasjoner. Pasienten ble henvist til ekkokardiografi for utredning av funnene.

De vanligste årsaker til venstre ventrikkelhypertrofi er hypertensjon, aortastenose og hypertrofisk kardiomyopati. Ekkokardiografi og MR-undersøkelse av hjertet står sentralt $\mathrm{i}$ utredningen.

Ekkokardiografi viste ujevn ekkotetthet og økt veggtykkelse av både venstre og høyre ventrikkels frie vegg og septum (fig 2). Det ble også påvist en liten mitralinsuffisiens uten hemodynamisk betydning. Den økte veggtykkelsen var mest uttalt $i$ apikale deler av septum. Det var ingen tegn til utløpsobstruksjon i venstre ventrikkel. Atriene var lett forstørret. Det var god systolisk funksjon i venstre ventrikkel, men vevsdopplerundersøkelse viste generelt reduserte vevshastigheter i myokard og forsinket relaksasjon, passende med diastolisk funksjonsforstyrrelse. Funnene ga samlet sett mistanke om restriktiv kardiomyopati.

På bakgrunn av de ekkokardiografiske funnene, som viste sannsynlig restriktiv kardiomyopati, ble det reist spørsmål om mulig avleiringssykdom med kardial affeksjon eller infiltrerende myokardsykdom. Kontrastforsterket MR-undersøkelse av hjertet ville kunne gi nærmere diagnostisk avklaring.

MR-undersøkelsen ble gjennomført med funksjonsserier i tre plan, T2-vektet kortakse før og T1-vektet serie i kort- og langakse etter intravenøs gadoliniumkontrast (fig 3). Undersøkelsen bekreftet ujevn myokardfortykkelse i begge ventrikler, spesielt fremtredende i septum. Begge atrier var lett forstørret, og det ble påvist lettgradige mitralog trikuspidalinsuffisienser, uten hemodynamisk betydning. Ejeksjonsfraksjonen ble estimert til $65 \%$ (> $60 \%$ ), og venstre ventrikkels myokardmasse ble beregnet til 135 g (70-180 g). Det ble påvist flekkevise, store områder med kontrastoppladning llate gadolinium enhancement, LGE), mest uttalt anteroseptalt og inferiørt i venstre ventrikkels myokard. Områder med kontrastoppladning var lokalisert sentralt i myokard eller transmuralt, men ikke subendokardialt. I tillegg ble det funnet noe perikard-
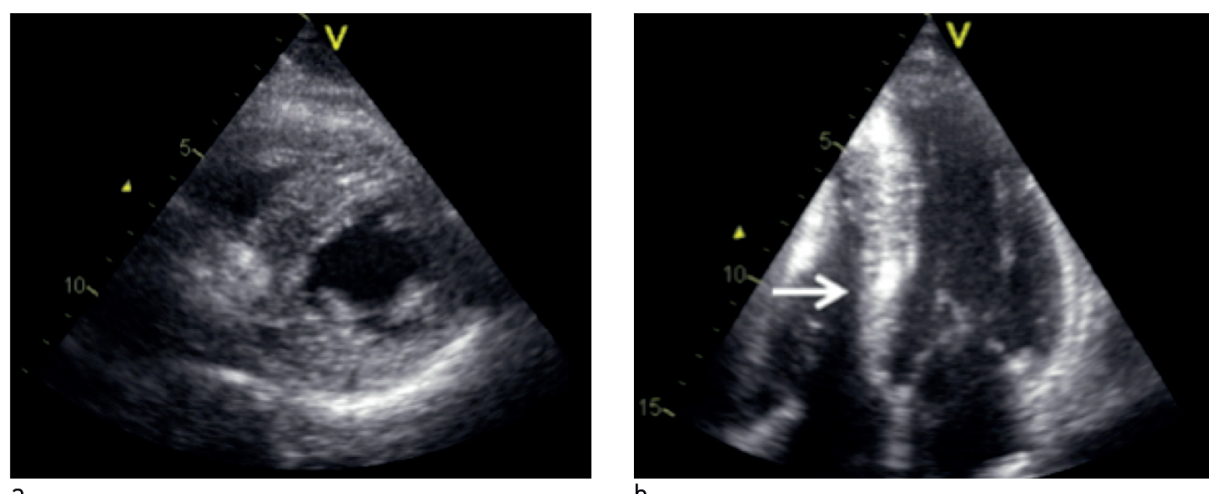

Figur 2 Ekkokardiografisk undersøkelse. a) Parasternalt kortaksebilde og b) apikalt firekammerbilde i diastolen. Bildene viser ujevn ekkotetthet og økte veggtykkelser av både venstre og høyre ventrikkels frie vegg og septum (pil)

væske samt flere forstørrede glandler, særlig i høyre hilusregion.

MR-undersøkelsen bekreftet diagnosen restriktiv kardiomyopati og styrket mistanken om avleiringssykdom i myokard. Med bakgrunn i de kardiale funn ble endomyokardial biopsi diskutert, men det vurdert som lite hensiktsmessig, da forandringene var ujevnt lokalisert. Muligheten for å treffe et patologisk område ble ansett som liten. Dessuten hadde pasienten uttalte forandringer i lungehilus. Biopsimaterialet fra dette området var så langt ikke representativt for konklusiv diagnostikk.

Under et tverrfaglig møte, ca. 14 måneder etter symptomdebut, ble det bestemt å ta ny biopsi og eventuelt fjerne hele tumoren i lungehilus ved torakotomi. Tumoren ble fjernet fra høyre lungehilus og sendt til histologisk undersøkelse og til dyrking med tanke på tuberkulose. Den histologiske undersøkelsen viste en forstørret lymfeknute gjennomsatt av granulomer, forenlig med sarkoidose. De kardiale forandringene ble derfor oppfattet som ledd i sarkoidose, og videre kardial diagnostikk i form av endomyokardial biopsi ble ikke ansett som nødvendig. Langtids EKGregistrering påviste ingen arytmi, kun sinusbradykardi. Man diskuterte, men fant ikke indikasjon for verken implanterbar defibrillator eller pacemaker. På grunn av sarkoidose med kardial affeksjon var det indikasjon for kortikosteroidterapi, og pasienten ble satt på prednisolon i langsomt avtrappende doser. Hun hadde god klinisk respons på kortikosteroidbehandling, som ble avsluttet etter to år. Pasienten er fortsatt under klinisk oppfølging. Kontroll-MR og ekkokardiografi har så langt ikke vist progrediering av sykdommen. Belastnings-EKG har vist at hun har god arbeidskapasitet, og lungefunksjonstester har også vært tilfredsstillende.

\section{Diskusjon}

Pasientens symptomer og funn ble oppfattet å være ledd i en restriktiv kardiomyopati. Kardiomyopati defineres som myokardsykdom med patologisk hjertemuskelstruktur og -funksjon i fravær av koronarsykdom, hypertensjon, klaffesykdom eller medfødt hjertesykdom (1). Ifølge oppdaterte europeiske retningslinjer fra 2008 deles kardiomyopati inn i familiær (genetisk form) eller ikke-familiær kardiomyopati (1).

Videre deles de i henhold til morfologi og funksjon inn i fem subgrupper: Hypertrofisk, dilatert, restriktiv og arytmogen høyre ventrikkel-kardiomyopati samt en gruppe kardiomyopatier som ikke lar seg klassifisere i en av de andre fire gruppene (1). Restriktiv kardiomyopati forekommer relativt sjelden og kjennetegnes av økt veggstivhet og redusert elastisitet, som innebærer restriktivt fyllingsmønster og diastolisk dysfunksjon.

Pasienter kan godt ha typiske hjertesviktsymptomer uten svekket systolisk funksjon når det foreligger diastolisk dysfunksjon, slik vår pasient fikk påvist. Dette kan man se ved for eksempel hypertensjon eller, som i dette tilfellet, infiltrerende myokardsykdom med øt veggtykkelse og veggstivhet. Restriktiv kardiomyopati kan være idiopatisk, familiær eller være ledd i ulike systemiske sykdommer, spesielt amyloidose, sarkoidose, karsinoid hjertesykdom, sklerodermi eller toksiske effekter av antrasyklinbehandling (1).

Sarkoidose er en granulomatøs sykdom med ukjent årsak som karakteriseres ved affeksjon av flere organer. Sykdommen forekommer hyppigst i nordeuropeiske land og rammer opptil 40/100 000 innbyggere per år (2). Symptomene vil avhenge av hvilke organer som er affisert, hyppigst er lungesymptomer. Diagnosen stilles vanligvis ved hjelp av histologiske undersøkelser av biopsimateriale (2). Omtrent $60 \%$ av sarkoidosepasientene har økte ACE-nivåer i plasma (2). Enzymet produseres av makrofager i sarkoide granulomer. Imidlertid har testen lav spesifisitet og sensitivitet og brukes derfor ikke diagnostisk (3). Vår pasient hadde lett forhøyet ACE-nivå i en prøve. Senere kontroller viste normalverdi.

Kardial sarkoidose er en underdiagnostisert sykdom som kan være til stede hos så mange som $25 \%$ av pasientene med systemisk sarkoidose (3). Diagnostisering kan være vanskelig, men kardial affeksjon bør 

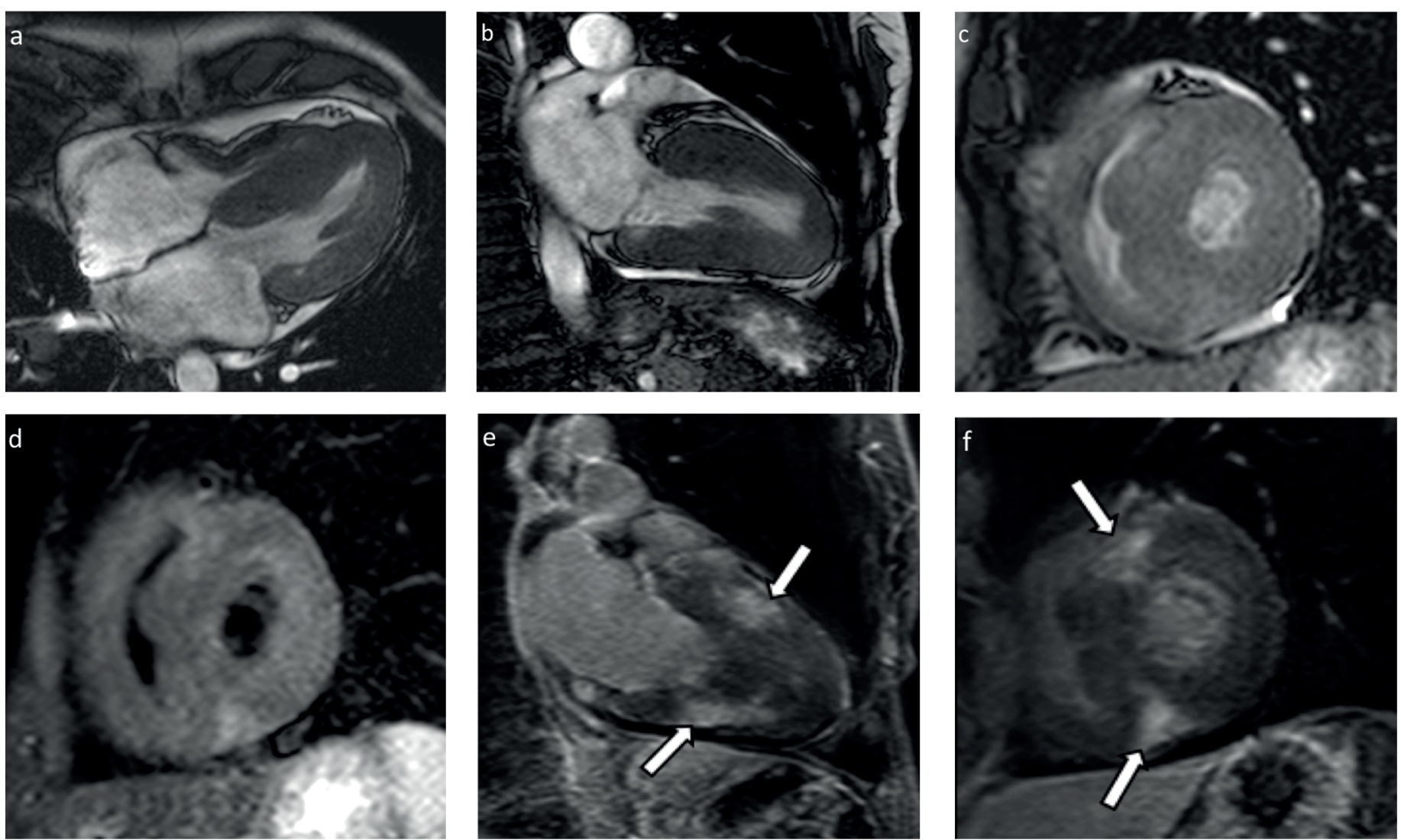

Figur 3 MR-undersøkelse. Funksjonsseriene viser fortykket myokard i begge ventrikler - al firekammer, bl langakse, cl kortakse, alle endesystole. d) T2-vektet serie før intravenøs kontrast demonstrerer økt signal. T1-senserier etter intravenøs kontrast demonstrerer flekkevis LGE (late gadolinium enhancement). Hvite pilere) langakse, f) kortakse

vurderes hos alle sarkoidosepasienter på grunn av forhøyet risiko for alvorlige hjertearytmier og plutselig hjertedød $(4,5)$. Et vanlig EKG bør tas ved første vurdering og ved senere oppfølging. Ved mistanke om kardial sarkoidose anbefales videre utredning og kartlegging, med henblikk på både diagnostikk, kardiale konsekvenser og prognose (4). Ekkokardiografi, MR, PET av hjertet og langtids EKG-registrering vil være aktuelt. Kardial affeksjon opptrer vanligvis sammen med sarkoidoseforandringer i flere organer, men kan også forekomme $\mathrm{i}$ isolert form, som da ofte ikke er erkjent. I vestlige land regnes hjerteaffeksjon å være årsak til $13-25 \%$ av sarkoidoserelaterte dødsfall, i Japan er kardial død ledende årsak hos sarkoidosepasienter (4). Sykdommen kan presentere seg med alt fra asymptomatisk venstre ventrikkel-dysfunksjon til manifest hjertesvikt, synkope, atrioventrikulær blokk, atrial eller ventrikulær arytmi og plutselig hjertedød (4).

Utgangspunktet for henvisning til ekkokardiografi for pasienten var bilyd og venstre ventrikkel-hypertrofitegn på EKG. Vår pasient hadde ikke QRS-kompleks med lav amplitude (low voltage) på EKG. Slike QRSkompleksforandringer ble tidligere oppfattet som nøkkelfunn ved avleiringssykdommer i myokard eller infiltrerende myokardsykdom, for eksempel ved amyloidose, men ses ikke alltid ved slike tilstander (6). EKG er angitt å være unormalt hos $60-75 \%$ av pasientene med kardial sarkoidose. Det vanligste funnet er ledningsforstyrrelser i form av atrioventrikulær blokk (4).

Endomyokardial biopsi har lav diagnostisk treffsikkerhet ved kardial sarkoidose $(<20 \%)$, fordi det er en tendens til at granulomene er lokalisert usammenhengende og spredt i venstre ventrikkel samt $i$ basale deler av septum fremfor i høyre ventrikkel, der endomyokardial biopsi vanligvis utføres (2). Den vanligste lokalisasjonen for sarkoide granulomer og arrdanninger er i venstre ventrikkels frie vegg, etterfulgt av ventrikkelseptum, ofte med involvering av ledningssystemet. Det understrekes at ekkokardiografiske funn ved kardial sarkoidose er heterogene og avhengig av i hvilket stadium sykdommen befinner seg. Man kan finne både tykke og tynne områder på grunn av henholdsvis granulomer og fibrosedanning (6).

Både MR og PET av hjertet er ansett som verdifulle undersøkelser i diagnostisering av kardial sarkoidose (2). Konsensuskriterier for diagnostisering av kardial sarkoidose er utviklet i Japan $(5,7)$. Disse kriteriene innebærer flere diagnostiske tester, inkludert EKG, ekkokardiografi og MR-undersøkelse for identifisering av kardial affeksjon når endomyokardial biopsi enten ikke er utført eller ikke er diagnostisk $(5,6)$. LGE-MR er en relativt ny teknikk som tillater visualisering av selv minimal myokardskade $\mathrm{i}$ form av arrvev og/eller nekrose (5). Et annet viktig aspekt er at funn av områder med kontrastoppladning ved MR kan ha prognostisk betydning, da selv små områder kan være assosiert med fremtidige kliniske hendelser i form av ventrikulære arytmier og andre ledningsforstyrrelser (5). Til tross for økt diagnostisk sensitivitet er verken LGE-MR eller PET spesifikke for kardial sarkoidose (4). De kardiale funnene hos vår pasient kunne i prinsippet representere for eksempel amyloidose, men vi vurderte at to så sjeldne sykdommer samtidig ville være usannsynlig.

Medikamentell behandling av sarkoidose er generelt erfaringsbasert. Tidlig bruk av høydose kortikosteroider er antatt å kunne stanse sykdomsprosessen og reversere hjerteskaden, men kontrollerte kliniske studier foreligger ikke (3). Man har likevel mest klinisk erfaring med kortikosteroider, og data om annen immunsupprimerende behandling er svært begrenset (8). Kardial affeksjon styrker indikasjonen for kortikosteroidbehandling $(3,5$, $8)$. Det er forskjellige synspunkter når det gjelder indikasjon, dosering og behandlingsvarighet. Vanligvis anbefales det oppstart med relativt høy dose, for eksempel prednisolon 30-40 mg daglig, deretter langsom nedtrapping til 5-15 mg i løpet av 6-8 uker. Vedlikeholdsbehandling med lav dose vil ofte være langvarig, i noen tilfeller livslang (8).

Pasienter med positiv LGE-MR-undersøkelse, atrioventrikulær blokk eller alvorlige 
ventrikulære arytmier bør vurderes med tanke på pacemaker eller implanterbar defibrillator $(5,7)$. Så langt foreligger ikke anbefalinger om primærprofylaktisk implanterbar defibrillator (Implantable Cardioverter Defibrillator, ICD) hos pasienter med kardial sarkoidose, men dette bør tilbys til overlevere etter hjertestans og ved refraktære ventrikulære arytmier (9). Ut fra mindre observasjonsstudier fra de senere år er det mye som tyder på en viss forbedring av prognosen ved sarkoidose, antakelig på grunn av bedre diagnostiske hjelpemidler og mer systematisk bruk av steroider i tidlig stadium, særlig før venstre ventrikkels systoliske funksjon er affisert (3).

Pasienten har gitt samtykke til at artikkelen blir publisert.

\section{Ziaullah Kamal (f. 1971)}

er spesialist $\mathrm{i}$ indremedisin. Han er assistentlege ved Kardiologisk avdeling ved Oslo universitetssykehus, Ullevål.

Forfatter har fylt ut ICMJE-skjemaet og oppgir ingen interessekonflikter.

\section{Geir Øystein Andersen (f. 1962)}

er dr.med. og spesialist i kardiologi. Han er overlege og forskningsansvarlig ved Kardiologisk intensiv- og overvåkingsavdeling ved Oslo universitetssykehus, Ullevål.

Forfatter har fylt ut ICMJE-skjemaet og oppgir ingen interessekonflikter.

\section{Gunnar Smith (f. 1948)}

er overlege ved Ekkosenteret, Kardiologisk avdeling, Oslo universitetssykehus, Ullevål. Forfatter har fylt ut ICMJE-skjemaet og oppgir ingen interessekonflikter.

\section{Frøydis Stornes (f. 1958)}

Spes i indremedisin og lungemedisin. Overlege lungeavdelingen OUS, Ullevål.

Forfatter har fylt ut ICMJE-skjemaet og oppgir ingen interessekonflikter.

\section{Knut Haakon Stensæth (f. 1961)}

er spesialist i radiologi, ph.d. og har spesialkompetanse innen kardiovaskulær diagnostikk og intervensjon. Han er overlege ved Avdeling for radiologi og nukleærmedisin, Enhet for thorax-og intervensjonsradiologi ved Oslo universitetssykehus, Ullevål, og medlem av styret i Norsk forening for intervensjonsradiologi. Forfatter har fylt ut ICMJE-skjemaet og oppgir ingen interessekonflikter.

\section{Jan Eritsland (f. 1950)}

er dr.med. og spesialist i indremedisin og hjertesykdommer. Han arbeider ved Kardiologisk avdeling, Oslo universitetssykehus, Ullevål. Forfatter har fylt ut ICMJE-skjemaet og oppgir ingen interessekonflikter.

\section{Litteratur}

1. Elliott P, Andersson B, Arbustini E et al. Classification of the cardiomyopathies: a position statemen from the European Society Of Cardiology Working Group on Myocardial and Pericardial Diseases. Eur Heart J 2008; 29: 270-6.
2. Iannuzzi MC Rybicki BA, Teirstein AS Sarcoidosis. N Engl J Med 2007; 357: 2153-65.

3. Dubrey SW, Falk RH. Diagnosis and management of cardiac sarcoidosis. Prog Cardiovasc Dis 2010; 52: $336-46$

4. Nunes H, Freynet O, Naggara N et al. Cardiac sarcoidosis. Semin Respir Crit Care Med 2010; 31 428-41.

5. Patel MR, Cawley PJ, Heitner JF et al. Detection of myocardial damage in patients with sarcoidosis. Circulation 2009; 120: 1969-77.

6. Seward JB, Casaclang-Verzosa G. Infiltrative cardiovascular diseases: cardiomyopathies that look alike. J Am Coll Cardiol 2010; 55: 1769-79.

7. Soejima K, Yada H. The work-up and management of patients with apparent or subclinical cardiac sarcoidosis: with emphasis on the associated heart rhythm abnormalities. J Cardiovasc Electrophysiol 2009. 20: 578-83.

8. Kim JS, Judson MA, Donnino R et al. Cardiac sarcoidosis. Am Heart J 2009; 157: 9-21.

9. Yeboah J, Lee C, Sharma OP. Cardiac sarcoidosis: a review 2011. Curr Opin Pulm Med 2011: 17 $308-15$

Mottatt 30.5. 2011, første revisjon innsendt 26.10 2011, godkjent 8.3. 2012. Medisinsk redaktør Mette Sagsveen.

\section{Kommentar}

\section{Når det mangler retningslinjer}

Under utredning og senere behandling av sjeldnere sykdommer tvinges klinikere til å gå til litteraturen for å få «oppskrifter» og råd som kan redusere deres usikkerhet i møtet med det uvanlige. Fremfor sprikende ekspertog konsensuserklæringer ønskes klare retningslinjer basert på randomiserte studier, slike som eksisterer for utbredte lidelser. Kamal og medarbeideres kasuistikk illustrerer at disse ikke alltid er innen rekkevidde.

Klassifisering av kardiomyopatier har vært utfordrende, og fortsatt er European Society of Cardiology og American Heart Association uenige om en hensiktsmessig inndeling $(1,2)$. Dette til tross for at organisasjonene har kommet med stadig flere felles inndelinger og retningslinjer for ulike områder innen kardiologien. Restriktive kardiomyopatier er en heterogen sykdomsgruppe med avleiring $\mathrm{i}$ myokard som fellestrekk. Avleiringsmønstrene er forskjellige, med ulike morfologiske og fysiologiske karakteristika. Sterkt varie- rende klinisk presentasjon og sykdommens sjeldenhet vil medføre hyppig feildiagnostisering. Vedvarende europeisk og amerikansk uenighet om kardiomyopatiinndelingen skaper forvirring heller enn sikrere diagnostikk og behandling.

Hyppigheten av kardial affeksjon ved sarkoidose er usikker. I kliniske studier er insidensen anslått til 5-10\%, ut fra autopsier til 20-60\%, mens det med MR og PET er påvist hjerteaffeksjon hos nærmere $40 \%$ av pasientene med sarkoidose (3). Klinisk presentasjon med ledningsforstyrrelser, ventrikulære arytmier eller hjertesvikt avhenger av lokalisering, utbredelse og sykdomsaktivitet. Selv om det eksisterer japanske konsensuskriterier for diagnosen kardial sarkoidose, har disse aldri vært prospektivt evaluert (4). Det er problematisk at det mangler sensitive diagnostiske metoder for en sykdom som kan gi opphav til alt fra symptomfrihet til plutselig hjertedød.
Heller ikke behandlingen av kardial sarkoidose er standardisert. Steroidbehandling er relativt ukontroversielt, men optimal dosering er uavklart. Det er mer usikkert hvorvidt asymptomatiske eller minimalt symptomatiske pasienter i det hele tatt skal behandles. Siden arytmi ikke ble påvist hos den aktuelle pasienten, valgte forfatterne å avstå fra spesifikk antiarytmisk behandling og/ eller implantere en defibrillator (Implantable Cardioverter Defibrillator, ICD). Mange kolleger vil støtte en slik vurdering, andre ville sett på avgjørelsen som for avventende. Ifølge amerikanske retningslinjer er kardial sarkoidose en rimelig indikasjon for å legge inn en ICD (anbefaling klasse IIa) (5). Bakgrunnen er sykdommens progredierende natur. Elektrofysiologisk undersøkelse kan bidra til vurderingen. Pasienter som har spontan eller indusert vedvarende ventriku- 